\title{
A Study on the Subsequent Measurement of Goodwill
}

\author{
Xiaoya Sang*
}

\author{
Beijing Jiaotong University, Beijing, China \\ *Corresponding author. Email: 912902598@qq.com
}

\begin{abstract}
This paper mainly studies the problems of goodwill follow-up measurement. Through using literal research and quantitative analysis, sort out the problems existing in the subsequent measurement of goodwill and put forward corresponding suggestions for improvement. The purpose is to promote the continuous improvement of the current accounting standards, standardize entrepreneur's behavior, and provide reliable basis for investors' decision-making.
\end{abstract}

Keywords: Goodwill, Subsequent measurement, Impairment test.

\section{INTRODUCTION}

Goodwill is an asset that can bring excess earnings to a company in the future and is one of the most important elements of a company's value.

According to its source, goodwill can be divided into purchased goodwill and self-generated goodwill, but the current accounting standards in China do not allow enterprises to recognize self-generated goodwill. The amount of goodwill is equal to the merger costs paid by the purchaser subtract the fair value of the share of identifiable net assets of the purchased party. At the same time, the current accounting standards also clearly rule that goodwill should be subsequently tested for impairment at least at the end of each year to determine whether goodwill maintains its original value.

However, it is undeniable that this method of subsequent measurement of goodwill still has many problems, such as strong subjectivity, relatively high cost, and difficulty in actual operation. In addition, with the further development of globalization of the world economy and the increasing number of overseas M\&A activities, the situation of a company's performance changing dramatically due to the impairment of purchased goodwill occurs from time to time, and the drawbacks of the impairment test method are becoming more and more prominent. Against this background, this paper discusses the subsequent measurement of goodwill based on the data of all A-share listed companies from 2015 to 2018.

\section{ORGANIZATION OF THE TEXT}

\subsection{Methods of Subsequent Measurement of Goodwill}

The first is the immediate elimination method, which means that after the determination of purchased goodwill, it is directly eliminated against equity, and is recorded in profit or loss or capital surplus. The reason for this method is that the value of goodwill is difficult to measure accurately, its useful life is also difficult to determine, and identifying it as an asset is contrary to the principle of prudence; and because the purchased party does not recognize self-generated goodwill, so this measurement also satisfies the principle of comparability. However, this approach also has obvious shortcomings, because the purchased goodwill may bring excess earnings to the enterprise in the future, it is unreasonable to recognize goodwill as an expense in the acquisition, which cannot reflect the economic substance of goodwill.

The second is the perpetual retention method, which involves keeping goodwill as an asset perpetually without impairment or amortization. The reason is that goodwill should be able to bring excess future earnings to the business, and as long as goodwill still has this ability, it should exist; also, because the buyer will continue to maintain the image of the business and its ability to generate surplus earnings, the value of goodwill should be constant. The flaw in this approach is that although goodwill does not periodically depreciate like other assets, but it is unrealistic to assume that its value remains constant. 
The third is the systematic amortization method, which is amortizing goodwill over a finite number of years. Companies generally use the straight-line method and count the amortization into the current profit and loss. The reason is that the development of enterprises has a life cycle, it is impossible to maintain competitive advantage in the market forever, and the goodwill cannot exist forever. It can only play a role in the limited life of the enterprise. In addition, because goodwill can only bring excess earnings to the enterprise within a limited period, amortizing its cost to profit and loss is also in line with the proportionality principle. However, this method cannot reflect the fluctuation of the value of goodwill, and if the value of goodwill increases, the accounting information will lack reliability; meanwhile, the amortization period of goodwill is difficult to be reasonably determined, thus this way greatly increases the space for surplus management of enterprises, and there is a large subjectivity.

Fourthly, the impairment test method, which is executing impairment test of goodwill regularly. The reason is that the value of goodwill is highly volatile and its recognition and measurement should not be based on a static approach, but be corrected in subsequent tests. This method is theoretically reasonable, but in practice there are certain shortcomings, such as the complex and difficult operation of impairment test. For small and medium-sized enterprises, it is not significant and the cost is too high; at the same time, the impairment test also has certain subjectivity in the practical application, which may expand the profit manipulation space of enterprises.

On January 1st, 2007, China's new accounting standards came into effect. ASBE No. 20 clearly states that the subsequent measurement of goodwill should be based on the impairment test instead of amortization method. ASBE No.8 also clearly states that the impairment test of acquired goodwill should be performed at least once at the end of each year. Since goodwill cannot generate cash flows on its own, subsequent impairment test needs to be performed together with its related asset group or combination of asset groups. The impairment test for an asset group should take into account both the recoverable amount and book value of the asset group. The amount of impairment equals the difference between the above two.

\subsection{Status and Problems of Subsequent Measurement of Goodwill of Listed Companies}

\subsubsection{Status of Goodwill in China's Listed Companies}

The following part takes the financial statement data of China's A-share listed companies from 2015 to 2018 as the object for analysis to understand the current situation of goodwill in China's listed companies and to explore the current problems in the implementation of listed companies.

Table 1. Overview of goodwill of listed companies from 2015 to 2018

\begin{tabular}{|l|l|l|l|l|}
\hline Year & 2015 & 2016 & 2017 & 2018 \\
\hline The amount of listed companies & 2776 & 2995 & 3432 & 3534 \\
\hline The amount of listed companies with goodwill & 1624 & 1802 & 1939 & 2044 \\
\hline The amount of listed companies with goodwill impairment & 258 & 348 & 496 & 899 \\
\hline Percentage of companies with goodwill & $58.50 \%$ & $60.17 \%$ & $56.50 \%$ & $57.84 \%$ \\
\hline $\begin{array}{l}\text { Percentage of companies with goodwill impairment among } \\
\text { listed companies }\end{array}$ & $9.29 \%$ & $11.62 \%$ & $14.45 \%$ & $25.44 \%$ \\
\hline $\begin{array}{l}\text { Percentage of companies with goodwill impairment among } \\
\text { companies with goodwill }\end{array}$ & $15.89 \%$ & $19.31 \%$ & $25.58 \%$ & $43.98 \%$ \\
\hline
\end{tabular}


Table 2. Amount and growth of goodwill of listed companies

\begin{tabular}{|l|l|l|l|l|}
\hline Year & 2015 & 2016 & 2017 & 2018 \\
\hline Total goodwill [hundred million yuan] & 6276 & 10187 & 12667 & 12736 \\
\hline Growth rate of total goodwill & - & $62.32 \%$ & $24.34 \%$ & $0.54 \%$ \\
\hline $\begin{array}{l}\text { Average amount of goodwill per company [hundred million } \\
\text { yuan] }\end{array}$ & 3.86 & 5.64 & 6.52 & 6.24 \\
\hline Growth rate in average amount of goodwill per company & - & $46.11 \%$ & $15.60 \%$ & $-4.29 \%$ \\
\hline Total impairment of goodwill [hundred million yuan] & 79 & 115 & 369 & 1668 \\
\hline Growth rate of total goodwill impairment & - & $45.57 \%$ & $220.87 \%$ & $352.03 \%$ \\
\hline $\begin{array}{l}\text { Average amount of goodwill impairment per company [ten } \\
\text { thousand yuan] }\end{array}$ & 3073.93 & 3266.48 & 7404.43 & 18563.47 \\
\hline $\begin{array}{l}\text { Growth rate of the average amount of goodwill impairment per } \\
\text { company }\end{array}$ & - & $6.26 \%$ & $126.68 \%$ & $150.71 \%$ \\
\hline
\end{tabular}

Table 3. Relative size of goodwill and impairment of listed companies

\begin{tabular}{|l|l|l|l|l|}
\hline Year & 2015 & 2016 & 2017 & 2018 \\
\hline Total net profit [hundred million yuan] & 11227 & 12876 & 17136 & 15949 \\
\hline Rate of change in net profit & - & $14.69 \%$ & $33.08 \%$ & $-6.93 \%$ \\
\hline Total goodwill [hundred million yuan] & 6276 & 10186 & 12668 & 12735 \\
\hline Percentage of goodwill in net profit ratio & $55.91 \%$ & $79.10 \%$ & $73.93 \%$ & $79.85 \%$ \\
\hline Total impairment of goodwill [hundred million yuan] & 79 & 115 & 369 & 1668 \\
\hline Percentage of goodwill impairment in net profit ratio & $0.71 \%$ & $0.89 \%$ & $2.15 \%$ & $10.46 \%$ \\
\hline Percentage of goodwill impairment in goodwill & $1.26 \%$ & $1.13 \%$ & $2.91 \%$ & $13.10 \%$ \\
\hline $\begin{array}{l}\text { Growth rate of percentage of goodwill impairment in } \\
\text { goodwill }\end{array}$ & - & $-10.32 \%$ & $157.52 \%$ & $350.17 \%$ \\
\hline
\end{tabular}

Table 1 shows that the number of listed companies, listed companies with goodwill, and listed companies with goodwill impairments from 2015 to 2018 are all growing. The above data show that the proportion of companies with goodwill impairment in listed companies, as well as the proportion of companies with goodwill impairment in companies with goodwill have increased rapidly from 2015 to 2018, and more and more listed companies have taken goodwill impairment.

According Table 2, we can find that the growth rate of goodwill impairment of listed companies, including the total impairment and the average amount, has greatly exceeded the growth of goodwill itself, the rise is very rapid, and the financial statement information of listed companies as well as the stability of the capital market may be affected.

From Table 3, we can know that the proportion of goodwill that companies are recording for impairment is increasing. In this case, subsequent measurement of goodwill using impairment testing is likely to have a substantial impact on profits.

From the above statistical analysis, we can see that the M\&A activities of listed companies in China are becoming frequent. The number of companies with goodwill and the amount of goodwill are increasing, and goodwill has become an important resource of companies. With the amount of goodwill impairment increasing, its impact on enterprise will become more obvious. Therefore, it is of great significance to study the problems in the current method of subsequent measurement of goodwill and improve it to provide information on the true financial status of enterprises.

\subsubsection{Issues in the Subsequent Measurement of Goodwill}

\subsubsection{Identifying Asset Groups and Combination of Asset Groups is Difficult}

ASBE No.8 specifies that subsequent impairment test of goodwill should be performed in conjunction with relevant asset group or combination of asset groups. The relevant asset group or combination of asset groups should be able to benefit from the synergies of the business combination and should not be larger than the identified reporting segments of the business.

The first difficulty with the goodwill impairment is the identification of relevant asset group or combination of asset groups. Identifying an asset groups requires consideration of factors such as whether the asset group 
generates independent cash inflows and managers' approach to managing the entity's assets. But "how to recognize the asset group and asset group combination", the standard does not have detailed provisions, which provides enterprises with more autonomy. In practice, when determining the impairment test object, an enterprise may choose a production line, a workshop or even the entire enterprise, and different selection will affect results of the goodwill impairment test.

\subsubsection{The Measurement of Recoverable Amounts from Asset Groups is Difficult}

It is clearly stated in ASBE No.8 that to determine the recoverable amount of an asset, the net of fair value of assets less disposal cost and the present value of estimated future cash flows should be considered. However, based on the current market conditions in China, it is difficult to obtain the fair value of assets. Where there is no active market, relevant valuation techniques are used to estimate fair value, but different valuation methods may yield different results, making it difficult to determine the net of fair value of an assets less disposal cost.

The standard also states that if an enterprise is unable to reliably estimate the net of fair value less disposal cost, it should consider the present value of the expected future cash flows of the asset as its recoverable amount. To determine the present value of the expected future cash flows, three factors must be considered, namely the useful life of the asset, the expected future cash flows from the asset and the discount rate. In practice, however, the estimation of the present value of future cash flows is difficult for the following reasons.

On the one hand, the projection of future cash flows relies on the company's good budget management, but in reality, some companies have not yet formed a comprehensive budget management system, and the projection of future cash flows is not supported by real and reliable data; on the other hand, due to the high degree of uncertainty of future profit from goodwill, the useful life of the relevant asset group or combination of asset groups are difficult to determine.

\subsubsection{Intangible Assets are Susceptible to Adjustment to Goodwill}

Accounting standards state that in recognizing and measuring the acquired party's assets, the first step is to identify intangible assets held by the acquired but not recognized in the financial statements, and should recognize them as intangible assets if the conditions are met.

In the consolidation activities, the purchaser will not only acquire the tangible assets and recognized intangible assets of the acquired, but also may acquire intangible assets held by the acquired but not recognized in the financial statements. According to the standard, enterprises should fully identify and reasonably judge these assets, and they should be recognized as intangible assets if conditions are met. However, at present, most listed companies in China directly recorded this part in goodwill, making the amount of goodwill inflated and unreal. By reviewing "2018 Annual Report on Accounting Supervision of Listed Companies" published by the SEC, we can find that the phenomenon of inadequate recognition of the acquired identifiable net assets and underestimation of their fair value is widespread in the M\&A activities of companies. The direct consequence of this practice is that intangible assets are undervalued and the amount of goodwill is inflated. Due to the differences in the methods of amortization and impairment of intangible assets and goodwill, including intangible assets in goodwill will avoid the negative impact of amortization of intangible assets on profits and inflate post-merger operating results of the company.

\subsection{Recommendations for Improving the Subsequent Measurement of Goodwill in China}

\subsubsection{Establish Guidance on the Identification of Asset Group Cases}

This paper suggests that the relevant standard-setting bodies can issue more detailed guidelines for identifying asset groups according to the industry classification of listed companies, study and compile cases for identifying asset groups, and clearly display the criteria for identifying asset groups in different industries through the form of cases to help enterprises to accurately identify asset groups, enhance the operability of accounting standards, reduce subjectivity and human factors in accounting operations, and enable accountants to have a basis in practical operations.

\subsubsection{Standardize the Measurement of Recoverable Amounts from Asset Groups}

Since it is currently difficult to obtain fair value in our market, most companies will recognize the present value of the expected future cash flows of the asset as the recoverable amount of the asset, so we need to strictly regulate the measurement of the recoverable amount of the asset group. We can start from the following two aspects: future cash flows and service life.

\subsubsection{Future Cash Flows}

It is necessary for enterprises to enhance their own budget management capabilities, as soon as possible to form a comprehensive and scientific budget management system to provide the necessary data to support the prediction of future cash flows. 
The standard clearly indicates that the expected future cash flow of an asset consists of three components, namely the expected cash inflow that can be obtained from the continual use of the asset, the expected necessary cash outflow and the expected net cash flow upon disposal of the asset. For the expected cash inflow component mentioned above, due to the presence of purchased goodwill in the asset group or combination of assets, a company's expected cash inflow should include not only the profits from identifiable assets, but also the unidentifiable goodwill.

\subsubsection{Service Life}

To address the issue of useful life, we can start with the nature of goodwill. Because goodwill is an unidentifiable asset that cannot exist alone, the value of goodwill apportioned to it will cease to exist if the useful life of the asset group or group of asset groups to which it relates ends, so its useful life should be aligned with that of the asset group or group of asset groups.

\subsubsection{Strictly Regulate the Recognition and Measurement of Intangible Assets in Mergers and Acquisitions}

China's accounting standards do not clearly define the scope of intangible assets. In practice, they only require the recognition and measurement of patents, on-patented technologies, trademarks, copyrights, franchises, land use rights, etc., while U.S. accounting standards recognize intangible assets by enumerating them one by one. Compared with the U.S. GAAP, China's current standards do not provide for a broader definition of intangible assets. There are not many types of intangible assets listed in the current standards, and the relevant recognition standards are not uniform enough.

From the perspective of current statements, goodwill contains too many factors, has a complex composition, and is subjective in measurement, making it a disaster area for accounting measurement. Therefore, for intangible assets in mergers and acquisitions, any intangible assets that can be separately recognized should be avoided to be included in goodwill. The fair value of intangible assets that could not be recognized by the buyer in the past can now be reliably measured, should also be separately recognized and not included in goodwill. In addition, the standard can also learn from foreign experience and issue relevant case guidelines to regulate the scope of intangible assets by enumerating them one by one, to clearly delineate the boundaries between intangible assets and goodwill, and to avoid the distortion of accounting information caused by the confusion between goodwill and intangible assets.

\subsection{Conclusion}

With economic development and the increasing number of corporate M\&A activities, goodwill has become an important issue that cannot be ignored. As scholars' research on goodwill gradually deepens, we believe that the subsequent measurement method of goodwill will continue to be improved and provide more reliable information for information users.

\section{ACKNOWLEDGMENT}

This research was financially supported by the National Science Foundation.

\section{REFERENCES}

[1] Allan Hodgson, John Okunev, Roger Willett. Accounting for Intangibles: A Theoretical Perspective [J]. Accounting \& Business Research, 1993, 23(90):138-150.

[2] James C. McCroskey, Jason J. Teven. Goodwill: A reexamination of the construct and its measurement [J]. Communication Monographs, 1999, 66(1):90-103

[3] Chalmers K, Clinch G, Godfrey J M. Adoption of International Financial Reporting Standards: Impaction the Value Relevance of Intangible Assets [J]. Australian Accounting Review, 2008, 18(3):237-247.

[4] Amel-Zadeh A, Faasse J, Li K, et al. Has Accounting Regulation Secured More Valuable Goodwill Disclosures? [J]. Available at SSRN 2306584, 2013.

[5] Su WH, Wells P. The association of identifiable intangible assets acquired and recognized in business acquisitions with post acquisition firm performance $[\mathrm{J}]$. Accounting \& Finance.2015, 55(4):1171-1199.

[6] Sahut, JM, Boulerne, S. and Teulon, F. Do IFRS provide better information about intangibles in Europe? [J]. Review of Accounting \& Finance, 2011, 10(3):267-290. 